\title{
ULASAN PENERBITAN JURNAL: \\ Ulasan Terhadap Beberapa Artikel dalam Journal of Shariah Law Research Edisi Pertama
}

\author{
Abdul Monir Yaacob \\ Professor, Head of Administration Council \\ Islamic University Malaysia \\ 63000 Cyberjaya, Selangor. \\ monir@uim.edu.my
}

Penyelidikan adalah antara satu di antara identiti sesebuah pusat pengajian tinggi di samping menjadi medan penyebaran ilmu melalui pengajian dan pembelajaran. Aktiviti penyelidikan lebih diberi keutamaan bagi universitiuniversiti yang diberi status universiti penyelidikan.

Dari mana datangnya idea mengkategorikan sesebuah institusi pengajian tinggi awam dan sekarang telah dijenamakan dengan universiti awam (UA) sebagai universiti penyelidikan. Apabila diteliti perkembangan dan perubahan dalam penstrukturan kementerian Pendidikan di Malaysia, telah ditubuhkan Kementerian Pengajian Tinggi. Pada ketika YB Dato' Dr. Shafie Hj. Mohd Salleh memegang jawatan Menteri Pengajian Tinggi, beliau telah menubuhkan "Jawatankuasa Mengkaji, Menyemak dan Membuat Perakuan Tentang Perkembangan dan Hala Tuju Pendidikan Tinggi Malaysia" pada 17 Januari 2005. Bertujuan untuk menjalankan kajian status pendidikan tinggi negara dalam konteks perkembangan pengajian tinggi serantau dan antarabangsa.

Hasil daripada kajian ini telah menyediakan laporan dan perakuan kepada Kementerian Pengajian Tinggi Malaysia berasaskan terma rujukan yang telah ditetapkan. Jawatankuasa yang dipengerusikan oleh YB Tan Sri Dato' Dr. Wan Mohd Zahid Mohd Nordin yang dianggotai oleh tokoh-tokoh akademik dan profesional telah diberi tempoh enam bulan untuk menyiapkan tugasnya. Ahli-ahli jawatankuasa ini telah mengadakan kunjungan ke institusi-institusi Pendidikan Tinggi terkemuka di seluruh dunia meliputi Amerika, Eropah, Asia Barat dan Asia. Penulis bersama dengan Prof. Dato' Dzulkifli Abdul Razak, Naib Cancelor USM (ketika itu) telah ditugaskan berkunjung ke Kanada dan Amerika dan bersama-sama dengannya Tan Sri Dr. Sulaiman Mahbob ke Asia Barat. Di antara tugas utama jawatankuasa ini yang ditetapkan adalah untuk mengemukakan perakuan-perakuan yang akan membolehkan Pendidikan Tinggi di Malaysia mencapai taraf dunia supaya dengan pencapaian tersebut 
menjadikan Malaysia sebagai pusat kecemerlangan serantau. (Ringkasan Eksekutif 1.2).

Penyelidikan adalah satu di antara tunggak kecemerlangan yang membezakan institusi pengajian tinggi (IPT) bertaraf dunia daripada IPT yang lain. Penyelidikan mencabar, merangsang dan mendorong para pemikir untuk meneroka ilmu dan memahami kehidupan manusia. Hala tuju IPT negara untuk meraih kecemerlangan dalam penyelidikan masih lagi jauh. Komposisi penuntut pascasiswazah daripada seluruh enrolmen penuntut di IPT tempatan berbanding IPT di negara-negara maju adalah amat kecil Berikutan dengan pendedahan ini Kementerian Pengajian Tinggi telah memberi penekanan kepada meningkatkan bilangan penuntut pascasiswazah di universiti awam terutama di universiti yang dikategorikan sebagai universiti penyelidikan.

Jawatankuasa tersebut telah membuat perakuan supaya universiti penyelidikan dan pascasiswazah diwujudkan dengan cara menjadikan universiti-universiti awam yang sedia ada yang menepati kriteria yang ditetapkan oleh Kementerian Pendidikan Tinggi sebagai universiti penyelidikan, pascasiswazah dan pascakedoktoran.

Universiti Malaya adalah di antara lima (5) universiti yang dikategorikan sebagai universiti penyelidikan. Akademi Pengajian Islam adalah sebahagian daripadanya. Bidang tumpuan penyelidikan bagi akademi ini tentunya lebih kepada bidang sains sosial, bagaimanapun bidang-bidang lain tidak diabaikan oleh universiti ini dan dilaksanakan oleh fakulti yang relevan seperti dalam bidang sains dan teknologi.

Ucapan tahniah wajar diberikan kepada Jabatan Syariah dan UndangUndang, Akademi Pengajian Islam kerana telah berjaya menghasilkan Journal of Shariah Law Research terutamanya kepada Ketua Jabatan, Dr. Siti Zubaidah Ismail dan Ketua Editor Jurnal, Profesor Dato' Dr. Ahmad Hidayat Buang di atas inisiatif yang telah diambil bagi menerbitkan jurnal ini. Objektif jumal ini antara lainnya adalah untuk menghebahkan dan menerbitkan hasil penyelidikan dalam bidang undang-undang Syariah.

Dalam penerbitan sulung jurnal ini memuatkan sembilan buah (9) penulisan yang semestinya sebahagian daripada kajian ilmiah atau tesis yang sedang dijalankan oleh pelajar-pelajar pengajian di peringkat sarjana dan kedoktoran dalam bidang undang-undang Syariah. Secara umumnya calon-calon di peringkat pascasiswazah ini menulis di bawah bimbingan penyelia masingmasing. Ini akan meletakkan kedudukan artikel yang ditulis itu lebih terjamin dan sudut metodologi dan kandungannya.

Beberapa penulisan dalam jurnal ini akan diberi ulasan. Di antaranya adalah artikel bertajuk, "Penggunaan Maqāṣid al-Syarī'ah dalam Fatwa Muamalat di 
Malaysia". Penulis atau pelajar calon Ph.D ini mendapat bimbingan daripada seorang profesor yang berwibawa dan berpengalaman dalam bidang tersebut. Perkara baru yang akan diberi penekanan dan pendedahan adalah penggunaan maqāsid al-Syarī'ah dalam fatwa muamalat.

Maqāṣid al-Syarī'ah bukan subjek baru. Telah banyak penulisan-penulisan dalam bentuk buku dan rencana Begitu juga penulisan yang menghuraikan tentang fatwa. Kedudukan perkara tersebut iaitu maqāșid al-Syarī'ah dan fatwa walaupun telah banyak penulisan mengenainya bagaimanapun masih terdapat segolongan masyarakat yang kurang faham dan keliru. Bidang muamalat yang disentuh di sini mungkin lebih fokus kepada kewangan Islam. Kerana muamalat secara umum memberi maksud yang amat luas termasuk bidang ekonomi dan sekuriti dalam Islam atau lebih khusus lagi pasaran modul Islam. Dari aspek akademi subjek muamalat dipelajari di sekolah-sekolah agama termasuk di peringkat pengajian tinggi. Masyarakat di Malaysia didedahkan dengan maqāṣid al-Syarī 'ah apabila kerajaan memperkenalkan indeks Syariah yang diasaskan kepada maqāșid al-Syarī'ah.

Baru-baru ini sebuah buku yang menghuraikan tentang maqāșid al-Syarī'ah telah dilancarkan. la ditulis oleh beberapa tokoh akademik dari pelbagai lapisan dan latarbelakang di peringkat antarabangsa. Buku bertajuk 'Defining Islamic Statehood'. Buku ini menghubungkan maqāșid al-Syarī'ah dengan negara Islam. Indeks maqasid berdasarkan kepada lima (5) tujuan utama iaitu nyawa, akal, nasab atau kehormatan harta dan agama.

Rencana yang ditulis oleh Norainan Bahari dan Ahmad Hidayat Buang lebih fokus kepada penggunaan maqāsid al-Syarī'ah dalam fatwa muamalat di Malaysia: Kajian literature. Terdapat tiga elemen penting iaitu fatwa, muamalat dan maqāssid al-Syarī'ah. Perkara yang hendak dilihat dalam rencana ini adalah sejauh mana literature fatwa muamalat berlaku dengan meluas dan menyeluruh dan ditulis oleh mereka yang berwibawa. Menurut penyelidik belum ada penulisan atau kajian menyeluruh yang mengkaji dan menganalisis fatwa tentang muamalat di Malaysia apatah lagi berkaitan dengan maqāṣid al-Syarī'ah. Walaupun telah ada sebuah tesis Ph.D yang ditulis mengenai maqāssid al-Syarī'ah oleh pelajar (ketika itu) Malaysia dan tesis itu telah diterbitkan oleh penerbit Dar el-salam, Mesir.

Penyelidikan tentang fatwa, ada tesis yang menghurai dan menganalisis tentang fatwa dalam buku 'Fatwa dalam Perundangan Islam' yang ditulis oleh Osman Ishak yang memfokuskan fatwa di negeri-negeri Melayu. Ahmad Hidayat Buang juga menulis tentang fatwa dalam buku bertajuk, 'Fatwa di Malaysia'. Isu muamalat berlaku dalam fatwa tentang wang simpanan di pejabat pos dan simpanan dalam kumpulan wang simpanan pekerja (KWSP) dan faedah dari simpanan di institusi-institusi tersebut yang dikeluarkan 
oleh mufti-mufti. Fatwa-fatwa tersebut tidak sekata dan tidak mengaplikasi maqāșid al-Syarī'ah.

Penggunaan maqāșid al-Syarī'ah dalam bidang muamalat yang terkini yang ada kaitan dengan fatwa adalah mengenai status ASN/ASB yang diterajui oleh Perbadanan Nasional Berhad (PNB). Fatwa daripada Muzakarah Majlis Fatwa Kebangsaan mengenai saham ASN/ASB adalah harus. Bagaimanapun, ia tidak diterima sepenuhnya oleh negeri-negeri. Fatwa tersebut berdasarkan prinsip 'maslahah' dan di bawah kategori 'qarurah'. Bagaimanapun fatwa di negeri Selangor tidak menerima hujjah tersebut. Pada pengamatan penulis (rencana ini) keharusan dihujjah atas lal-hajjiyat. Dalam perlaksanaan hukum ada wajib, sunat dan harus. Merujuk kaedah-kaedah fiqh 'Asal pada sesuatu itu ibahah atau harus'. Mengikut pengamatan penulis fatwa Muzakarah Majlis Fatwa Kebangsaan adalah betul.

Perlu juga diketengahkan persoalan sejauh mana Majlis Syariah Suruhanjaya Sekuriti mengambil kisah unsur-unsur maqāșid al-Syarī'ah dalam menentukan kategori saham patuh Syariah. Dalam hubungan ini timbul pula isu di pihak mana mempunyai autoriti dalam menentukan garis panduan sekuriti patuh Syariah. Adakah terbatas ke pada Majlis Syariah atau pada Majlis Fatwa Kebangsaan /Fatwa Negeri-Negeri.

Artikel kedua yang akan diberi ulasan ringkas adalah tentang penulisan, "Logo Halal". Artikel ini mengulas persepsi pengguna Muslim terhadap pemakaian logo halal yang dikeluarkan oleh JAKIM yang terdapat dalam literature mengenainya. la ada kaitan dengan sensitiviti pengguna muslim dalam keutamaan daya beli dengan makanan halal.

Selain JAKIM, negeri-negeri juga ada kuasa untuk mengeluarkan logo halal di samping logo-logo halal yang dikeluarkan oleh agensi-agensi di luar Malaysia yang memproduk makanan halal termasuk oleh negara-negara bukan Islam seperti Australia, Thailand, Vietnam dan Iain-lain. Dari masa ke semasa halal festival diadakan. Malaysia dilihat sebagai hab halal dunia. Menurut Dato' Seri Dr. Ahmad Zahid Hamidi, Timbalan Perdana Menteri Malaysia, Malaysia menghadapi saingan dalam produk halal dan pengusaha-pengusaha produk datang dari pelbagai lapisan pemilik industri termasuk dari kalangan bukan Islam. Seperti juga dengan kewangan Islam. Ia bukan lagi menopoli institusi-institusi Islam.

Persoalan yang diketengahkan sejauh mana peranan maqāșid al-Syarī'ah mempengaruhi dasar pengeluaran logo halal. Sebagai contoh, adakah modal bagi pembuatan atau industri halal itu diambil kira samada modal yang digunakan halal atau sebaliknya. Mungkin juga disyaratkan modal untuk produk makanan halal itu hendaklah seratus peratus dari sumber halal. 
Berbangkit dari pemakaian logo halal adalah penguatkuasaan undangundang. JAKIM sebagai pengeluar logo halal tidak berkuasa secara bersendirian mengambil tindakan undang-undang terhadap pihak yang memalsukan logo atau salahguna logo, termasuk juga ketidakpatuhan terhadap syarat penggunaan logo setelah memperoleh logo halal. JAKIM tidak boleh bertindak sendirian. Pematuhan logo halal di Singapura patut diberi perhatian. Suatu yang positif dalam penggunaan logo halal adalah persepsi oleh pengguna bukan Islam terhadap makanan yang mempunyai logo halal, seperti mana penerimaan dan persepsi mereka terhadap perbankan Islam di negara ini.

Seterusnya tajuk rencana ketiga 'Keluar Agama Islam di Malaysia'. Perlembagaan Persekutuan menentukan bahawa Raja atau Sultan adalah ketua agama bagi negerinya (Perkara 3 (2)). Bagi tujuan pentadbiran agama Islam, setiap negeri termasuk Wilayah-wilayah Persekutuan, masing-masing mempunyai Undang-undang Pentadbiran Agama Islam (dengan tajuk yang berbeza). Dalam undang-undang tersebut terdapat beberapa peruntukan yang menentukan bagaimana seseorang itu masuk Islam. Sebagai contoh dalam Enakmen Pentadbiran Agama Islam, Negeri Selangor 2003 bahagian ix ada beberapa peruntukan yang menyatakan tatacara bagi mana-mana orang yang memeluk agama Islam.

Tiada peruntukan tentang keluar agama Islam. Bagaimanapun, Mahkamah Tinggi Syariah diberi kuasa di bawah peruntukan 61(3) (b) (x) iaitu pengisytiharan bahawa seseorang itu bukan lagi orang Islam. Artikel tersebut menyebut memang terdapat permohonan keluar agama Islam. Direkodkan di Mahkamah Syariah ada menerima sebanyak 863 permohonan keluar agama Islam sepanjang tahun 2000-2010. Ini adalah satu jumlah yang mengejutkan dan membimbangkan. Enakmen Pentadbiran Agama Islam Negeri Selangor 2003 tidak menyediakan apa-apa peruntukan bagi permohonan keluar Islam, begitu juga dengan kebanyakan.

Enakmen Pentadbiran Agama Islam di lain-lain negeri. Bagaimanapun, enakmen Pentadbiran Agama Islam Negeri Sembilan 2003, Seksyen 119 ada membuat peruntukan tentang pemohon keluar agama Islam. Permohonan hendaklah dibuat secara ex parte kepada hakim Mahkamah Tinggi Syariah oleh orang yang berhasrat untuk meninggalkan agama Islam sebagai agamanya, dengan menyatakan alasan dan disokong oleh suatu affidavit yang menyatakan semua fakta yang menyokong alasan permohonan itu. Peruntukan tersebut memberi peluang untuk membuat pemohon keluar daripada agama Islam di Negeri Sembilan.

Secara umumnya kebanyakan Enakmen Pentadbiran Agama Islam telah dipinda dengan memberi bidangkuasa kepada Mahkamah Tinggi Syariah 
untuk mengisytiharkan seseorang itu bukan lagi orang Islam. Akan tetapi, tiada tatacara dan garis panduan tentang bagaimana persiytiharan ini boleh dilakukan berbanding dengan Negeri Sembilan. Permohonan daripada individu tertentu untuk menukar status agamanya masih berlaku masa ke semasa. Sama ada individu ini menukar status agamanya daripada agama bukan Islam dengan masuk Islam atau sebaliknya dan berlaku juga kepada remaja bawah umur.

Perlembagaan Persekutuan Perkara 11 membuat peruntukan tentang kebebasan agama; akan tetapi tertakluk kepada Fasal (4) mengembangkan agamanya. Tidak ada peruntukan jelas tentang kebebasan menukar agama dalam perlembagaan negara. Kebebasan menukar agama terdapat dalam perkara 18 Deklarasi Sejagat Hak Asasi Manusia (UDHR) PBB yang menyatakan bahawa;

"Setiap orang adalah berhak kepada kebebasan berfikir, perasaan hati dan agama, hak ini termasuk kebebasan menukar agama atau kepercayaannya"

Hak kebebasan menukar agama ini telah dibincang di peringkat drafting committee, Suruhanjaya Hak Asasi Manusia PBB yang dipengaruhi oleh The World Council of Churches. Cadangan tersebut telah menimbulkan kontroversi dan bantahan daripada beberapa buah negara Islam, termasuk kerajaan Arab Saudi kerana peruntukan tersebut jelas bertentangan dengan Islam.

Realiti yang berlaku permohonan keluar daripada agama Islam ada yang dibuat kepada Mahkamah Tinggi Syariah dan ada yang dibuat kepada mahkamah sivil. Dan ada negeri yang menentukan keluar daripada agama Islam sebagai satu kesalahan jenayah di bawah enakmen kesalahan jenayah Syariah.

Bagi sesetengah pihak ada yang terus membuat permohonan ke mahkamah sivil. Dalam kes Menteri Dalam Negeri lwn. Jamaludin bin Othman, ${ }^{1}$ Hashim Yeop Sani, H.B. di Mahkamah Agung berkata;

"Hakim yang membicarakan kes itu telah bertentang sematamata atas perkara 11 Perlembagaan Persekutuan mengenai kebebasan beragama."

Dalam kes tersebut responden telah menukar pegangan agamanya kepada agama Kristian.

Dalam kes Majlis Agama Islam Negeri Sembilan, ${ }^{2}$ Mahkamah Tinggi Seremban telah memutuskan bahawa di dalam kes Cik Nurul Ain masih kekal

\footnotetext{
$1 \quad$ Menteri Dalam Negeri lwn. Jamaludin bin Othman (1989) 1 MLJ 418.

2 Majlis Agama Islam Negeri Sembilan (1992) 2 Kanun (1) 137.
} 
dengan Islam. Keputusannya untuk keluar daripada agama Islam melalui affidavit bahawa dia berhasrat untuk meninggalkan agama Islam belum boleh disifatkan muktamad dan mahkamah tinggi sivil tidak ada bidang kuasa untuk mendengar apa-apa perkara yang berada dalam bidang kuasa Mahkamah Syariah.

Dalam kes Dalip Kaur lwn. Pegawai Polis Bukit Mertajam, ${ }^{3}$ soal sama ada seorang itu yang telah menganut agama Islam telah murtad atau tidak telah dirujuk kepada Majlis Agama Islam Pulau Pinang. Majlis Fatwa Pulau Pinang dalam fatwanya atau lain menyebut:

"Untuk menentukan sama ada seseorang telah terkeluar daripada Islam (murtad) atau tidak, hendaklah terlebih disabitkan oleh mana-mana Mahkamah Syariah dan dihukum sebagai terkeluar daripada Islam (murtad). Jika tidak ada disabitkan oleh manamana Mahkamah Syariah dan dihukum, maka seseorang itu tetap hidup dalam agama Islam."

Dalam kes Lina Joy lwn. Majlis Agama Islam Wilayah Persekutuan \& Anor, ${ }^{4}$ Ketua Hakim Negara dalam penghakimannya menyatakan bahawa perkara 11 (1) Perlembagaan Persekutuan tidak wajar dihujahkan sebagai peruntukan yang memberi hak kebebasan yang tidak terbatas. Cara seseorang untuk keluar daripada sesuatu agama semestinya mengikut kaedah atau undang-undang atau amalan yang ditentukan atau yang ditetapkan oleh agama itu sendiri.

Keadaan yang membatas dan tidak memberi kebebasan sepenuhnya kepada pihak yang hendak keluar daripada agama Islam telah menimbulkan golongan yang tidak puas hati dan seterusnya membuat bantahan hingga ke peringkat Pertubuhan Bangsa-Bangsa Bersatu berkenaan dengan hak asasi manusia di Geneva.

Secara umumnya artikel yang dimuatkan dalam jumal ini menyentuh masalah semasa yang memerlukan beberapa penjelasan dan penyelesaian. Semoga hasil daripada penyelidikan oleh calon-calon Ph.D di Jabatan Syariah dan Undang-undang akan dapat membantu pihak-pihak berkenaan bagi mengetahui isu-isu yang ditimbulkan dengan memberi perhatian dan mengambil tindakan yang sewajarnya. Adalah merugikan jika penyelidikan yang begitu baik diabaikan oleh pihak-pihak berkenaan.

\footnotetext{
3 Dalip Kaur lwn. Pegawai Polis Bukit Mertajam (1992) 1 MLJ 1.

4 Lina Joy lwn. Majlis Agama Islam Wilayah Persekutuan \& Anor (2007) 4 MLJ 585 .
} 
Journal of Shariah Law Research (JSLR) 